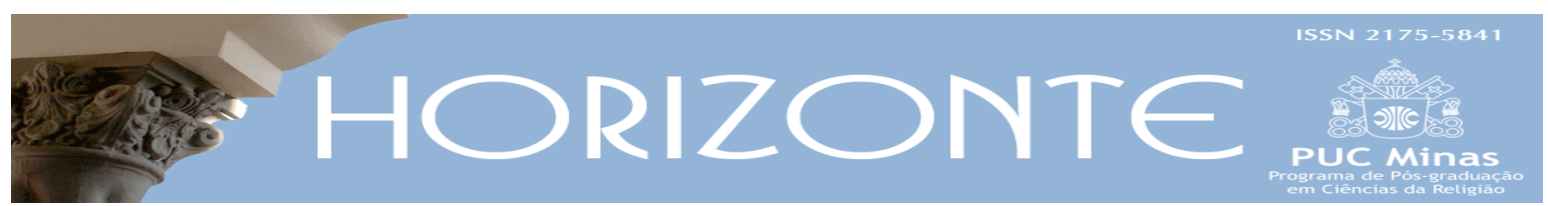

Temática Livre - Artigo original

DOI - 10.5752/P.2175-5841.2019v17n54p1544

\title{
O pluralismo eclesial: da contradição à afirmação do Evangelho
}

\author{
Ecclesial pluralism: \\ from contradiction to the affirmation of the Gospel
}

Elias Wolff*

\begin{abstract}
Resumo
O artigo objetiva analisar o pluralismo eclesial no mundo cristão, as tensões e os conflitos que aí existem, mas também as possibilidades de encontro no testemunho do Evangelho. Pelo método da análise qualitativa da bibliografia pertinente ao tema identifica, de um lado, fatores socioculturais e teológicos do pluralismo que são expressões de contradição na compreensão e vivência da fé cristã. De outro lado, aponta para elementos que podem favorecer a superação das divisões. Mostra que para isso se faz necessário um redimensionamento da leitura teológica do pluralismo de igrejas verificando as possibilidades para um reconhecimento das legítimas motivações de fé, para assumir as exigências do diálogo e para rever os pressupostos da separação dos cristãos. Como resultado, compreende-se que o pluralismo eclesial não implica diretamente apenas em divisão da igreja, mas pode expressar também possibilidades distintas da fidelidade ao Evangelho. Assim, a superação da divisão cristã não se dá pelo cancelamento de um sadio pluralismo eclesial, mas pela interação entre diferentes tradições eclesiais no testemunho da unidade da fé em Cristo, "para que o mundo creia" (Jo 17,21).
\end{abstract}

Palavras-chave: Pluralismo eclesial. Divisão cristã. Evangelho. Diálogo. Ecumenismo.

\begin{abstract}
The article aims to analyze the ecclesial pluralism in the Christian world, the tensions and conflicts that exist there, but also the possibilities of meeting in the witnessing of the Gospel. By the qualitative analysis method of the available bibliography identifies, on the one hand, socio-cultural and theological factors of pluralism that are expressions of contradiction in the understanding and experience of the Christian faith. On the other hand, it points to elements that may favor to overrun of divisions. For this it is necessary a resizing of the theological reading of the pluralism of churches seeking to verify the possibilities for a recognition of the legitimate motivations of faith, assume the demands of the dialogue and strengthen the availability to review the presuppositions of the separation of Christians. As a result, it is understood that ecclesial pluralism does not directly imply only the division of the church, but can also express distinct possibilities of faithfulness to the Gospel. Thus, the overcoming of the Christian division is not due to the cancellation of a healthy ecclesial pluralism, but by the interaction between different ecclesial traditions in the testimony of the unity of faith in Christ, "for the world to believe" (Jo 17,21).
\end{abstract}

Keywords: Ecclesial pluralism. Christian division. Gospel. Dialog. Ecumenism.

Artigo submetido em 15 de outubro de 2018 e aprovado em 2 de novembro de 2019.

* Doutor em Teologia pela Pontifícia Universidade Gregoriana. Professor do Programa de Pós-graduação em Teologia da PUCPR. Bolsista de Produtividade do CNPq. País de origem: Brasil. E-mail: elias.wolff@pucpr.br 


\section{Introdução}

A divisão é um drama espiritual dos cristãos. Teologicamente, é expressão do pecado que se manifesta pelas contradições, incompreensões, falta de caridade na comunidade cristã. Por isso ela não se justifica no Evangelho. Acaso a separação dos cristãos pode ser fruto de um modo coerente de compreender e afirmar o Evangelho? Se a resposta for positiva não deveria, então, fragmentar e criar contradições na igreja. As divisões "não são expressões de uma legítima multiformidade na unidade, mas divisões da unidade numa multiplicidade contraditória” (KASPER, 2002, p. 255).

Mas nem tudo no pluralismo eclesial é expressão de divisão. Urge uma leitura teológica desse pluralismo para verificar em que medida expressa ou contradiz a vontade de Cristo para a sua igreja una e única. Historicamente o pluralismo de igrejas é visto negativamente. Mas assim como a graça do amor divino se manifesta também em situações de ambiguidades e incoerências humanas, podemos perguntar se para além da divisão o pluralismo eclesial não pode conter também elementos pelos quais os cristãos podem fortalecer juntos sua fidelidade a Cristo. Já foi afirmado que "As divisões são sim obras do homem, mas são também permitidas por Deus. Nelas se verifica uma divisão dos espíritos, mediante a qual deve vir à luz a fidelidade dos cristãos. Elas são provas escatológicas" (KASPER, 2002, p. 255).

Este estudo busca verificar em que medida diferentes igrejas podem expressar algo mais que divisão na vivência da fé cristã e se apresentar como legítimas expressões do Evangelho. Constatando que algumas expressões eclesiais decorrem naturalmente da mensagem da Boa Nova, pergunta-se pelos critérios que ajudam para compreender que outras forçam os Evangelhos para se afirmarem em suas doutrinas e em suas práticas. O fato é que certamente o Evangelho não impõe uma única forma eclesial como condição para vivê-lo fielmente. Mas não é tarefa simples legitimar a atual variedade de igrejas como igualmente evangélicas. Dois objetivos são buscados neste artigo: verificar se o Evangelho possibilita de fato a 
diversidade eclesial que constatamos na atualidade; e quais as contradições existentes nessa diversidade que precisam ser superadas para um testemunho comum do único Evangelho. Os resultados apontam caminhos para, de um lado, afirmar um pluralismo eclesial que não seja divisão da igreja; e, de outro lado, superar os elementos de divisão entre os cristãos sem negar o valor do pluralismo eclesial que tem como fonte o único Evangelho.

\section{Fatores socioculturais do pluralismo eclesial}

O pluralismo eclesial tem a ver com o modo como cada região entendeu e viveu o Evangelho. Após afastar-se da matriz cultural do judaísmo, o cristianismo penetrou na cultura grega, latina, germânica, anglo-saxônica, céltica..., formando novos estilos de vida e paradigmas culturais para regiões inteiras. Isso mostra que a fé cristã não é abstrata, é vivida conforme o substrato cultural das pessoas e dos povos. O caráter de universalidade do Evangelho permite diferenciações na sua vivência. E o mesmo esforço para ser fiel ao Evangelho é dedicado também para manter as tradições socioculturais das comunidades de fé. Culturas diversas podem fazer surgir, e até o exigem, expressões diversas do único Evangelho. Na mesma comunidade cristã surgem distintas percepções e comportamentos cristãos. Isso é positivo se permanecem fieis à tradição dos apóstolos (Jd 3).

Contudo, a história do cristianismo mostra que tal fato não é sem tensões. Diferentes estilos e paradigmas da vida cristã entram em conflito em determinados momentos da história. Na ruptura dos nestorianos e monofisitas nos séculos IV e $\mathrm{V}$, manifestaram-se as diferenças das culturas grega e oriental na compreensão do dogma; no distanciamento progressivo entre Ocidente e Oriente, sobretudo do século IX ao XI, mesclaram-se questões teológicas como o Filioque, o uso de pães ázimos na celebração eucarística, o purgatório, a epiclese na consagração eucarística, com questões culturais e disciplinares como o celibato dos padres, expressando as diferenças de mentalidade entre gregos e latinos; na divisão do Ocidente cristão no século XVI, os debates teológicos sobre a justificação, os meios da graça, a hierarquia, se deram no contexto cultural da modernidade, marcada 
pelo pensamento humanista; e no século XX, novas expressões da fé cristã se afirmam com base ao princípio da liberdade religiosa e cultural, sustentando comunidades eclesiais diferentes. Algumas dessas intuições e percepções teológicas, espirituais e pastorais são autênticas e tem um sadio desenvolvimento. Têm o seu lugar na vida e na fé da igreja. Outras expressam a perda da tradição apostólica, a desagregação da comunidade eclesial, o distanciamento de outras comunidades.

Assim, o atual pluralismo eclesial é o resultado de processos complexos que envolvem questões socioculturais e teológicas que configuram uma identidade eclesial e um estilo de vida com uma estrutura de idiossincrasias psicossociais, preconceitos, resistências e lembranças que nem sempre favorecem as relações entre as igrejas. As controvérsias teológicas, espirituais, pastorais e culturais que aí existem, em muitos casos são mais do que simples tensões oriundas de diferentes vivências da fé cristã. Expressam divergências profundas na hermenêutica da fé e na organização da comunidade. E causam desequilíbrios de posições na comunidade cristã, como os constatados no distanciamento entre hierarquia e comunidade, Bíblia e doutrina, fé e obras devocionais, lutas por poder, antagonismos socioculturais, entre outros. E desse modo, as igrejas constroem separadamente um patrimônio próprio, em oposição e mútua exclusão.

\section{Da pluralidade à divisão da Igreja}

O problema começa quando a diferença torna-se divergência, contradição e oposição entre pessoas e comunidades cristãs. Então o que poderia ser expressão de um entendimento mais amplo, que favoreceria o testemunho comum do Evangelho, torna-se fator de fragmentação do corpo eclesial. E "Quando a diversidade destrói a unidade visível do corpo, então muda de natureza e torna-se divisão pecaminosa" (CONSELHO MUNDIAL DE IGREJAS, 2001a, n. 97). Por isso, as diferenças deixam de ser um enriquecimento para o conjunto dos cristãos. Elas 
se encarnam em comunidades separadas, de modo que os cristãos não são mais capazes de receber e transmitir a verdade no interior da única comunidade de fé, a comunhão se empobrece e isso é sofrido na memória viva da igreja. Porque os cristãos crescem separados, aspectos complementares da única verdade são, às vezes, percebidos como incompatíveis um com o outro. (CONSELHO MUNDIAL DE IGREJAS, 2001a, n. 97).

Quais são, de fato, as razões dessa realidade? Quando se estuda a história da divisão dos cristãos, é difícil o consenso sobre suas causas, motivações e objetivos. Pode-se entender a divisão cristã como fruto da rebeldia de pessoas que se opuseram às definições conciliares do seu tempo (século V) e às orientações das lideranças eclesiásticas (séculos XI e XVI), elaboraram novas concepções teológicas da fé e formaram grupos de seguidores, rompendo com a comunhão. E pode-se entendê-la também como fruto da coerência da fé que, entre outros fatores, não permite incluir novidades não bíblicas na terminologia da doutrina - como hommousios na cristologia, filioque na trinitária, transubstatio na Ceia. Somam, ainda, para as divisões o fechamento da igreja estabelecida aos questionamentos e exigências por mudanças e reformas que se fazem necessárias nos diferentes contextos da história.

A divisão dos cristãos vai além das diferenças de ênfases na doutrina cristã. Ser católico romano, ortodoxo, protestante, anglicano, pentecostal, diz respeito ao modo de entender e viver o conjunto das verdades do Evangelho. É mais do que acentuar aspectos da fé cristã. A essência da divisão pode ser apresentada sinteticamente, não sem riscos de ser simplório, do seguinte modo: para todos os fiéis em Cristo, a fé e a vida cristã são constitutivas de um conjunto coerente do ser cristão e da igreja. Mas divergem no modo de conceber esse conjunto. Esses modos aos poucos se transformam em divergências também de conteúdo e constituem uma tradição, uma confissão, uma nova identidade religiosa. O desafio é apresentar a totalidade da própria fé em novas expressões aceitáveis também por outros. E o diálogo torna-se difícil quando se é habituado apenas ao próprio modo de entender e viver a fé, ignorando a tradição dos outros e conservando opiniões que frequentemente deturpam a verdadeira posição. Persiste sempre um núcleo 
irredutível de desacordo entre modos diferentes de entender o Evangelho de Cristo e a sua igreja (CONSELHO MUNDIAL DE IGREJAS, 2001b, n. 6).

A saída desse impasse é entender que

a pluralidade confessional que separa é apenas provisória; pede a conversão para uma pluralidade confessional compatível com a unidade eclesial [...]. A conversão eclesial em direção à unidade exige, da parte das igrejas confessionais, a admissão da culpa que permita sair do status quo confessionalista. (GRUPO DE DOMBES, 1999, n. 1138).

\subsection{0 fator humano nas divisões}

A divisão entre os cristãos é marcada tanto por uma série de mal entendidos, quanto pela falta de disponibilidade para entender as razões do outro. Tanto no passado quanto no presente observa-se que posturas se radicalizam, absolutizando um determinado elemento da fé cristã e da igreja. Há uma dificuldade estrutural chave: a concepção de autoridade e a centralização do poder, que desvalorizam propostas alternativas à explicitação da fé e à organização da comunidade eclesial. Aprendemos isto com a história: na divisão do século $\mathrm{V}$, nunca se soube o que realmente Nestório teria a dizer no concílio de Éfeso, pois ele sequer foi ouvido no concílio. O concílio de Calcedônia fundiu a fé em Cristo com a linguagem que a expressou, excomungando quem não aceitou sua fórmula cristológica; nas controvérsias do século XI, estava claro o jogo de poder entre Roma e Constantinopla, além das dificuldades de comunicação entre Oriente e Ocidente; em nosso tempo, novas características culturais, como interpretações da liberdade e da individualidade, tem intensificado a fragmentação do cristianismo pelas expressões pentecostais. Em todos esses casos há acusações e hostilidades mútuas que impedem compreender que as diferenças de posições poderiam oferecer enriquecimentos específicos na compreensão e vivência da fé, numa complementariedade e comunhão reais. 
Certamente, o fator humano está na raiz dos elementos causadores e perpetuadores de divisão. Entre os causadores, estão o fechamento em posições individualistas; a coação ou perseguição que leva grupos a buscarem se libertar através da fragmentação; a discriminação por motivos socioculturais ou religiosos; o radicalismo de "reformadores" ou "revivalistas" que rejeitam o diálogo; os antagonismos culturais, nacionais ou as guerras e suas consequências (THILS, 1965, p. 11). Dos fatores que perpetuam a divisão, destacam-se a duração ou recordação dos fatores acima apresentados; a tendência psicológica em aceitar o status quo de separação como "normal"; a não compreensão das reais motivações dos envolvidos nas controvérsias que levaram à separação; a imagem errada que se tem das outras igrejas; novos fatores que nascem das igrejas separadas - grupos sociais, sentimento denominacional de apego ao próprio patrimônio teológico e espiritual, peso da instituição, espírito de combate, rejeição da renovação. Esses fatores agravam-se pela falta de diálogo e de caridade que possibilitam uma compreensão mútua. Em situações de tensão e de conflito, procura-se afirmar a identidade cristã e eclesial com posturas de autodefesa e de oposição acima dos elementos de convergência e de comunhão.

\subsection{Culpa de ambos os lados}

Nas discórdias e distanciamentos entre as igrejas há culpa de ambos os lados. Os extremismos, radicalismos e exclusivismos não são de uma parte apenas, como afirmou João Paulo II aos Membros do Conselho da Igreja Evangélica da Alemanha, em 17/11/1980:

Não queremos julgar-nos uns aos outros (Rm 14, 13). Mas queremos reconhecer juntos a nossa culpa. Isto vale também para a graça da

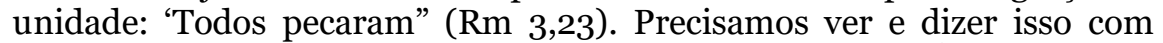
toda seriedade e daí tirar as consequências para nós. (JOÃO PAULO II, 1980). 
Reconhecer a culpa é, de um lado, um ato de humildade que evita colocar-se na postura de posse da verdade frente ao outro e de julgá-lo como o único no erro. De outro lado, a humildade leva a aprender com os erros, próprios e dos outros. Abrem-se assim o caminho para trabalhar pela superação dos males que estão na raiz da divisão dos cristãos.

No início do seu pontificado, o papa Paulo VI fez um pronunciamento no qual admitia culpas na divisão dos cristãos: "Se nas causas da separação pode-se nos imputar alguma culpa, dela pedimos humildemente perdão a Deus e pedimos também o perdão dos irmãos que se sentiram por nós ofendidos" (PAULO VI apud GRUPO DE DOMBES, 1999, n. 1153). Durante as discussões sobre o esquema De oecumenismo, em 18/11/1963, o Cardeal José Elmer Ritter, Arcebispo de SainLouis, EUA, afirmou:

É, portanto, necessário reconhecer a responsabilidade que tiveram os católicos no doloroso fato da separação. Temos o hábito de atribuir aos outros a culpa da divisão. Ora, quem estuda a história vê que não estamos isentos de culpa. Assim, a vida escandalosa de alguns prelados, na época da Reforma; da mesma forma, os métodos empregados contra os reformadores depois da separação. (RITTER apud BOAVENTURA, 1964, p. 309).

O mesmo cardeal propôs que "o Concílio fizesse uma confissão das culpas dos católicos neste ponto e que pedisse perdão aos irmãos separados afirmando, ao mesmo tempo, que a Igreja Católica não conserva o mínimo rancor pelo que sucedeu no passado" (RITTER apud BOAVENTURA, 1964, p. 309). Naturalmente, é de se crer que os fatores causadores da divisão não são intencionais, mas movidos por um verdadeiro amor à igreja e ao Evangelho. Contudo,

Mesmo se fizemos o que julgamos ter sido justo, devemos recordar que somos culpáveis no pecado não cometido inteiramente por nós e que não podemos dissociar-nos do pecado da divisão. A confissão da unidade com Cristo exige necessariamente a confissão da nossa solidariedade com os nossos irmãos no pecado. (CONSELHO MUNDIAL DE IGREJAS, 2001a, n. 98). 
Mas não é uma questão apenas do passado. Os cristãos do presente precisam reconhecer a própria culpa no estado atual de divisão entre as igrejas. O papa João Paulo II mostra que além das divergências doutrinais as divisões do mundo cristão são frutos de "equívocos e preconceitos de uns relativamente aos outros" (JOÃO PAULO II, 1995, n. 2); que "a responsabilidade (da separação) não pode ser atribuída somente aos outros" (JOÃO PAULO II, 1995, n. 11); e que "a unidade dos cristãos é possível com a condição de estarmos humildemente conscientes de ter pecado contra a unidade, e convencidos da necessidade da nossa conversão." (JOÃO PAULO II, 1995, n. 34). Essa conversão possibilita a "purificação da memória”, pelo reconhecimento do próprio erro e perdoando o erro dos outros, compreendendo que muitos deles são cometidos com a intenção de expressar fidelidade à própria consciência e ao Evangelho.

Assim, em nossos dias, o diálogo entre as igrejas possibilita essa consciência: "Reconhecemo-nos culpados do fato que estas diferenças tenham dividido as nossas igrejas e que a divisão tenha ofuscado o nosso testemunho do Cristo, causando dor aos homens e aos povos" (COMISSÃO INTERNACIONAL CATÓLICO-LUTERANA, 1986d, n. 1409). Pelos fatores "causadores" ou "perpetuadores" da divisão, somos

todos igualmente culpados; até que cada partido na nossa igreja não sente o ferrão da culpa, até que cada um de nós não experimenta o embaraço quando é obrigado a identificar-se com o seu partido, não pode haver nenhum crescimento substancial rumo à unidade cristã. (FÉ E CONSTITUIÇÃO, 2005, n. 688).

Por isso, não se recompõe a unidade da igreja com simples reagrupamento de pessoas, doutrinas, instituições. A unidade não é algo mecânico, que acontece como consequência lógica do ajustamento de realidades externas. Para superar essa situação, o caminho é a conversão (UR 8). É preciso começar a partir do Espírito, na interioridade de cada fiel e da igreja como um todo e, como consequência, os elementos exteriores se expressarão em comunhão. 


\subsection{A divisão como pecado}

O Concílio Vaticano II entende a divisão dos cristãos como "contradiçãa", "escândalo" e "obstáculo" (UR 1). São três termos que expressam a gravidade da situação de desentendimentos e a falta de comunhão em que vivem os cristãos: 1) é contradição do projeto de Deus Pai de formar de todos os povos um só (LG 9). Projeto que se expressa na ação de Cristo e seu desejo que todos os seus discípulos "sejam um" (Jo 17,21). Consequentemente, contradiz a natureza mesma da fé Cristã, que deveria ser vivida "no mesmo Espírito" (2Cor 4,13) de Cristo que a todos reúne na mesma fé, mesma esperança e mesma caridade (2Cor 13,13). 2) É escândalo para o mundo porque os cristãos deixam de dar um testemunho convincente do Deus no qual creem, pregam e que o mundo espera. Frustram as esperanças que o mundo tem de unidade e de paz. 3) É um obstáculo ao evangelho, em dois âmbitos: internamente, porque impede a comunidade eclesial de viver na caridade evangélica, a solidariedade e a comunhão, características do discipulado de Cristo. E externamente, porque dificulta a pregação do evangelho do amor e da paz ao mundo. Entendendo que "o mensageiro já é mensagem", como o mundo poderá acolher e crer no Evangelho se aqueles que o proclamam não o vivem em sua essência de amor, perdão, paz e unidade?

"Contradiçãa", "escândalo" e "obstáculo", é o que se pode entender aqui como "pecado" e consequência do pecado que impede aos cristãos o testemunho comum do Evangelho. Tal é a realidade dramática da divisão dos cristãos e da igreja. "A história não atesta algum escândalo maior do que essa fratura da fraternidade na Igreja de Cristo" (FÉ E CONSTITUIÇÃO, 2005, n. 687). O “Pecado" se expressa não pelas diferenças legítimas no interior do cristianismo, mas pela fragmentação e divisão do corpo místico de Cristo, sua igreja, o que acontece por atitudes e iniciativas que impedem a vivência da caridade fraterna, a convivência pacífica e a cooperação na missão entre as diferentes tradições eclesiais. Não se pode entender isso como algo normal da vida cristã e eclesial. 
Assim sendo, à pergunta sobre qual é a causa mais profunda da divisão da igreja, respondemos que na raiz de todas as causas está o pecado. Na igreja como sociedade histórica não opera apenas o poder do Espírito. Mesmo os que possuem o Espírito, e por isso são unidos a Cristo, têm também a realidade negativa do egoísmo, do orgulho, da falta de caridade e de fé. Infelizmente o pecado é mais visível do que a santidade, a divisão se expressa mais do que a comunhão. A divisão é, em última instância, expressão do pecado. Como os corações humanos têm dificuldades para se deixarem possuir plenamente pelo Espírito, e muitos mesmo possuindo "as primícias do Espírito" (Rm 8,23), são ainda governados pela obstinação, a fidelidade ao Evangelho da comunhão e abertura para a graça da unidade não é plena. Por isso a forma histórica e manifestação exterior da igreja não é ainda adequada à sua verdadeira natureza:

hoje Deus nos deu uma nova compreensão do pecado que caracteriza a situação de divisão que herdamos [...] (pecamos) quando [...], possuindo "a nossa igreja" para nós mesmos, considerando a nossa teologia, constituição, história, nacionalidade, etc., como um nosso "precioso tesouro" e afundando sempre mais no pecado da separação. (CONSELHO MUNDIAL DE IGREJAS, 2001a, n. 98).

Essa consciência nos chama à uma profunda conversão e somente assim pode haver progressos nos esforços pela recomposição da unidade visível da igreja. Como ensina o n. 7 de Unitatis redintegratio, "Não há verdadeiro ecumenismo sem conversão", o que possibilita reconhecimento das culpas contra a unidade cristã, revisão de vida e decisão por reformas necessárias para viver na comunhão em Cristo. É porque a igreja é uma fraternidade em Cristo que a divisão dos cristãos é um pecado, por contradizer o evangelho da unidade e do amor que Ele nos ensinou. É essa realidade de pecado que urge superar no atual contexto de pluralismo eclesial. 


\subsection{Motivações de fé}

Cada igreja entende-se enraizada na fé, o pluralismo eclesial expressa motivações de fé. Na origem de cada tradição eclesial há um princípio de fé. Essa é uma situação paradoxal: a fé está na origem das diferenças e das divergências da sua própria compreensão e vivência.

A fé tem expressão individual e comunitária. Pessoas de fé estão na origem da organização de comunidades de fé. Alguns julgam que outros se distanciaram da estrutura eclesial e da fé que Deus deu à igreja e suas pretensões são injustificáveis; outros se sentem chamados por Deus para uma reforma na vivência da fé e da constituição da igreja, e entendendo devolverem-lhe sua condição original criam novos modelos de igreja; há os que julgam que a fé deve ser reformada no interior mesmo das igrejas existentes; e há quem entende que as igrejas tradicionalmente constituídas não permitem na atualidade uma autêntica proclamação da palavra de salvação, originando igrejas "mais livres". Em tudo isso, "iniciativas de consciente obediência à vontade de Deus produziram, sem querer, fraturas na comunhão cristã no nível de doutrina, sacramentos, constituições" (CONSELHO MUNDIAL DE IGREJAS, 2001a, n.98).

Um dado é fato: as controvérsias teológicas tem originalmente a intenção de confessar a fé cristã e prestar um serviço à igreja, não buscam a divisão. Infelizmente, tal intento não chegou a bom termo, como se constata na história do cristianismo: motivações de fé cristológica estão na raiz das separações ocorridas no século V; a fé trinitária está na base da divisão entre Oriente e Ocidente no século XI; as ordens mendicantes clamaram por reformas na igreja medieval por amor e fé à igreja; os reformadores protestantes do século XVI entendem-se fundamentados na fé na justificação unicamente em Cristo; em nossos dias o movimento pentecostal compreende afirmar a fé na ação renovadora do Espírito Santo. Em meio a discórdias humanas, observa-se também a fé e o amor ao Evangelho: "Quando criticava os diversos aspectos da tradição teológica e da vida da igreja do seu tempo, Lutero se considerava uma testemunha do Evangelho, um 
“indigno evangelista de Nosso Senhor Jesus Cristo” (COMISSÃO INTERNACIONAL CATÓLICO-LUTERANA, 1986a, n. 1527). Pode-se questionar a compreensão, o conteúdo e a expressão da fé. Mas a fé como tal é o que se constata como razão de ser das diversas comunidades cristãs. O questionamento é válido para perceber as contradições e ambiguidades que podem aparecer mesmo em nome da fé. Por causa das fragilidades e do pecado humano, pode ocorrer que pensando zelar pela fé, cai-se também em algum tipo de heresia, precisamente o que se busca condenar no outro.

\subsection{Da fé para a doutrina}

Uma complexidade maior está no fato de que logo se passa do primado da confissão da fé para a definição e determinação da verdade, por fórmulas e cânones normativos. Mesmo com o objetivo de manter a comunhão na fé, há "perda da forma da invocação e da confissão na formulação da verdade [...] o risco de perder a referência mesma da verdade e exaltar a fórmula, a enunciação” (RUGGIERI, 2000, p. 22). A fé passa a ser entendida não mais como experiência, mas como enunciado teórico, que se observa mesmo se não entendido racionalmente e não vivido existencialmente. Ora, a "experiência" concreta da comunhão com Cristo não é a mesma para a "consciência" da verdade teologicamente definida. No dogma, "Emerge um conceito de verdade como confim, voltado para a delimitação do que nos diferencia do outro. Mas este conceito é possível somente no contexto de uma ruptura da comunhão e é funcional na manutenção desta ruptura” (RUGGIERI, 2000, p. 23).

A igreja, católica/universal em sua essência recebe um distintivo, uma espécie de redução na sua catolicidade, pela delimitação e divisão confessional. Isso começou com o Codex Theodosianum (438), que torna a igreja oficial no império romano, confirmado pelo Codex de Justiniano (529-534). A partir de então, ser católico é a única expressão da reta fé, e começam as perseguições legais das heresias. Mas essa redução confessional não é partilhada por todos os cristãos. Os ortodoxos entendem-se na fé católica, participando da comunhão na vida trinitária, 
com uma eclesiologia eucarística e sucessão episcopal. Igualmente os reformadores do século XVI não entendem estarem limitando a catolicidade da fé, compreendem-se na tradição da igreja antiga da qual não se separaram quando romperam com a forma de ser da igreja de Roma.

Contudo, as dificuldades de expressão das próprias ideias, de um lado, e a falta de entendimento e diálogo, de outro, levou da confissão de fé ao confessionalismo. Da reforma da fé almejada pelos reformadores protestantes, surgiram confissões eclesiais. E da contrarreforma católica em Trento, surgiu o tridentismo. Em ambos os casos houve enrijecimento das posições, em doutrinas e instituições diferentes. Na medida em que a fé católica é centralizada na Eucaristia, na veneração aos santos, sobretudo Maria, no ministério do papa, o protestante é identificado com o que não crê em nada disso e, portanto, "não tem fé" - ignora-se que ele crê na salvação em Cristo, tem amor à Palavra, dá testemunho do Evangelho, tem sua celebração da Ceia. Dessa forma, a identidade confessional torna-se referência para a identidade eclesial. E cada confissão considera-se a única dotada de verdadeira eclesialidade. A fidelidade à identidade eclesial confunde-se com a fidelidade às fórmulas doutrinais. O simples questionamento às formulações de fé, mesmo se para favorecer a unidade, é visto como ameaça para a eclesialidade. E a identidade eclesial define a identidade cristã: estar nesta igreja consiste em ser verdadeiro cristão, sendo falsos cristãos os da outra igreja.

\section{Redimensionando a leitura teológica do pluralismo eclesial}

A questão a ser verificada é a possibilidade de entender o pluralismo eclesial para além da marca de negatividade pela qual ele é normalmente visto. Não se trata de diminuir a gravidade do que falamos acima, desconsiderando os efeitos negativos que o pluralismo de igrejas pode expressar para a comunhão cristã. Mas de buscar compreender também em que medida a graça pode ter se servido desse fato para possibilitar diferentes expressões do Evangelho para os nossos tempos. A leitura ecumênica dessa realidade ajuda a reconhecer que, 
em sua misericórdia, Deus serviu-se dessas decisões (que levaram à divisão) para salvar almas, constituir comunidades que o adoram e preservar ou recuperar certos aspectos da sua verdade [...] atualmente, Ele dá-nos nova consciência do pecado que caracteriza a divisão dos cristãos, convida ao arrependimento. (CONSELHO MUNDIAL DE IGREJAS, 2001a, p. 98).

A sabedoria de Deus pode criar realidades positivas por caminhos inusitados e onde haveria apenas tragédia se houvesse somente a ação humana. Deus pode servir-se do pecado para pedagogicamente revelar seu projeto de amor à humanidade e chama-la à conversão.

\subsection{Igrejas: manifestações plurais da fé}

O pluralismo eclesial tem o potencial de expressar a amplitude de possibilidades na percepção da fé em Jesus Cristo e das experiências eclesiais cabíveis nas Escrituras. Os elementos que formam a expressão da fé cristã numa tradição eclesial não eliminam a universalidade do evangelho e a catolicidade da igreja, que podem se manifestar em horizontes teológicos, espirituais e institucionais distintos. Tal é o que podemos verificar pela exegese bíblica e a história da igreja. Mas o reconhecimento desse fato não é tranquilo entre as igrejas. Para isso, elas precisam saber explorar as condições de encontro e de diálogo no universo eclesial plural, o que implica reconhecer ali valores de fé que, de alguma forma, dizem respeito a todas as igrejas. Elas são desafiadas a reconhecerem-se mutuamente nesses elementos, num horizonte eclesial amplo do que o que é próprio de cada uma. Fundamental é que ali se reconheça, de fato, o conteúdo do Evangelho. Pois "mesmo não afirmando que todas as igrejas são iguais, pode-se dizer que todas as reais vivências do Evangelho são eclesiais" (WOLFF, 2007, p. 31). O fato de essas vivências não acontecerem em uma mesma forma eclesial não nega o significado cristão e eclesial comum que é conferido ao vivido. Dessa forma as igrejas podem reconhecer sintonias, convergências e, inclusive, consensos na fé que assume múltiplas formas de expressão. Assim, não há porque deslegitimar uma experiência sincera da fé apenas porque ela não acontece dentro dos padrões estabelecidos por uma determinada tradição eclesial. Ao mesmo tempo em que a fé 
acontece num contexto eclesial concreto, ela não apenas origina e sustenta esse contexto, mas também o transcende, de modo que a fé pode ser vivida de outras formas em outros contextos, impulsionando um encontro dos diferentes modelos eclesiais de compreensão e vivência do Evangelho.

O reconhecimento de valores de fé no interior do pluralismo eclesial, leva à pergunta pela legitimidade desse pluralismo. Ao se acolher o conteúdo da vivência cristã emerge o questionamento sobre a legitimidade da forma dessa vivência. Reconhecer que o Evangelho é verdadeiramente vivido em diferentes contextos e em diferentes formas implica fazer uma adequada distinção entre o que é essencial e fundamental na vivência cristã e o que é relativo. Isso implica em não amarrar o Evangelho nos critérios que as igrejas apresentam para a vida cristã. O fim é maior que os meios. Não se quer com isto afirmar algum relativismo ou fragilizar os elementos identitários das tradições eclesiais. O que se pretende é afirmar que o Evangelho tem primazia por ser o conteúdo da fé, como o essencial e fundamental para a vida cristã. E isso é chave para a convivência e o mútuo enriquecimento das igrejas: reconhecer o Evangelho vivido nas diferentes tradições eclesiais.

Se tal é possível, pode-se então, de um lado, reconhecer a fé comum no mesmo Evangelho. De outro lado, é possível estabelecer convergências na forma de vivê-lo. E isso conduz a um comum e amplo significado de igreja no qual os cristãos podem entender-se copartícipes do "Povo de Deus", "Corpo de Cristo”, “Templo do Espírito”. O encontro dos batizados nesse horizonte eclesial amplo não cancela as divergências eclesiológicas existentes, mas as coloca num espaço de diálogo sereno e verdadeiro. E podem assumir juntos projetos de missão que possibilitem o testemunho comum do Evangelho. O mútuo reconhecimento da fé no presente abre caminhos para o futuro mútuo reconhecimento eclesial. 


\subsection{O mundo plural como possibilidades para o diálogo}

A questão a responder é: qual a possibilidade de reconhecer legítimas motivações de fé no pluralismo eclesial do nosso tempo? Qual o nível de verdade e de erro evangélico que aí se manifesta? Os cristãos expressam a convicção de que não se pode transigir com a verdade. E, bem intencionados, entendem que a sua verdade está em sintonia com a verdade que se origina em Deus, nos Evangelhos. Mas a dificuldade de apresentar provas de uma missão recebida do "Alto" faz com que justamente essa "verdade" é o que os outros tenham dificuldade para compreender.

O desafio que se apresenta como urgente é discernir as interpelações e o significado do pluralismo eclesial para a comprensão do Evangelho e da igreja em nossos dias. Isso requer uma apurada sensibilidade teológica para olhar além do interior de cada tradição eclesial. Essa sensibilidade é, de um lado, enraizada nas próprias convicções e doutrinas. Vemos os outros a partir do que somos e cremos. Mas, de outro lado, para poder colher valores no mundo plural é fundamental que eles sejam reconhecidos no outro tal como é, e não unicamente a partir de nós. Assim, precisamos cuidar para que as nossas convicções e doutrinas mais orientem do que determinem o modo como compreendemos os outros. Trata-se de desenvolver uma compreensão mais evangélica do que doutrinal. No coração dos nossos valores há espaço para o reconhecimento dos valores dos outros. Isso requer uma disponibilidade para acolher o que se manifesta além das próprias fronteiras. Com essa sensibilidade e disponibilidade, é possível discernir as interpelações do pluralismo eclesial. Enquanto não formos exercitados para esse discernimento, tais interpelações podem ser vistas com resistência e temor. Mas na medida em que aprofundamos o olhar e reconhecemos no pluralismo eclesial o Evangelho vivido, esse reconhecimento apresenta a exigência da comunhão. Fundamental é compreender que para acolher o significado do Evangelho que nos interpela no contexto eclesial plural se faz necessário uma leitura teológica que vá além da simples constatação fenomenológica dessa realidade. O pluralismo eclesial não é apenas expressão, no âmbito religioso, do pluralismo cultural no qual a sociedade 
vive. Pois a natureza do pluralismo eclesial é teológico-doutrinal, embora socioculturalmente contextualizado. E uma doutrina religiosa mesmo se enraizada na sociedade a transcende. Essa compreensão deveria ajudar as igrejas a superarem tendências fixistas no modo como justificam teologicamente a sua presença no meio social. Evitar-se-ia, assim, que a multiplicidade de igrejas seja expressão apenas de divergências e contradições em relação ao conteúdo comum da fé cristã. O Evangelho que elas vivem aponta para a comunhão.

Nesse contexto, a teologia ecumênica precisa ser corajosa e profética. Precisa analisar criticamente o fenômeno do pluralismo eclesial, discernindo os fatores de divisão e as positivas perspectivas eclesiais diferenciadas do Evangelho. Alerta para as interpelações do pluralismo eclesial à consciência de cada igreja, indicando multiformes possibilidades para o diálogo e a comunhão na fé. Mostra que o pluralismo eclesial precisa deixar de ser “escândalo” e “contradição” ao Evangelho, ele pode ser também sua afirmação. De fato, a primeira intenção de cada igreja é afirmar a fé no Evangelho de Jesus Cristo, e não opor-se à outra igreja, de modo que o pluralismo eclesial é o resultado de afirmações de fé. Se considerarmos os eventos da Reforma do século XVI, vemos que na origem das divisões que dali surgiram entre os cristãos está um verdadeiro zelo de fé, uma vontade sincera de servir ao Evangelho. Assim foi com Lutero, Melanchthon, Calvino, Wesley e tantos outros. Na consciência dos reformadores as questões que levaram a separações, não eram enfrentadas como mera especulação intelectual, mas com uma postura de fé, pois diziam respeito à fé. Lutero era convicto que os seus protestos estavam em harmonia tanto com o Evangelho quanto com a fé da igreja. E muitas doutrinas que nasceram ao longo das reformas nos séculos XVI e XVIII, distinguem-se umas das outras mais pelo modo de afirmarem a fé do que pelo conteúdo dessa afirmação. Portanto, essa constatação fortalece a nossa tese de que o pluralismo eclesial não expressa apenas divisão, mas também possibilidades diferenciadas da compreensão e vivência do Evangelho'. Abrir caminhos de diálogo entre essas

\footnotetext{
${ }^{1}$ Tal é o que conclui o diálogo entre algumas igrejas: “Lá onde a Igreja e as comunidades eclesiais confessam segundo a Escritura Jesus Cristo verdadeiro Deus e verdadeiro Homem, como o único mediador da salvação para a glória de Deus, do Pai, do Filho e do Espírito Santo, existe uma fundamental unidade na fé" (COMISSÃO INTERNACIONAL CATÓLICO-LUTERANA, 1986C, N. 26).
} 
diferenças, diminuindo as contradições e amenizando o potencial escandaloso da divisão, é uma das principais tarefas da teologia em nossos dias. É o que afirma o diálogo católico-ortodoxo:

Longe de excluir a diversidade ou a pluralidade, a koinonia a pressupõe e cura as feridas da divisão, transcendendo-a na unidade. Como Cristo é um para os muitos, assim na Igreja, que é o seu corpo, o um e os muitos, o universal e o local, são, necessariamente, simultâneos [...]. Porque o Deus uno e único é comunhão de três pessoas, a Igreja una e única é comunhão de mais comunidades [...]. A Igreja una e única se identifica com a koinonia das igrejas. Unidade e multiplicidade aparecem ligadas a um ponto tal que a una não poderia existir sem a outra. É essa a relação constitutiva da Igreja que as instituições tornam visíveis e, por assim dizer, historicizam. (COMISSÃO INTERNACIONAL CATÓLICOORTODOXA, 1986, n.2).

Isso implica pensar um modo de ser igreja que se configure pela integração das diferenças. Oscar Cullmann (1986, p. 7-8) propôs como modelo de igreja a "unidade na diversidade", ou melhor, uma diversidade reconciliada, na qual as diferenças podem causar tensão mas nunca divisão. Elas tensionam para avançar no enriquecimento da comunhão na fé que as igrejas professam. Cullmann orienta que para isso é preciso reconhecer o que na tradição de cada igreja pode ser acolhido como dom Espírito, um carisma, que não pode ser cancelado sob pena de negar nelas a ação divina.

\section{Exigências do diálogo}

A pergunta que buscamos responder é sobre a possibilidade de conservar o pluralismo de igrejas superando o significado de divisão que ele pode expressar. É possível assumir um pluralismo eclesial que indique algo para além de discórdia na compreensão e vivência do Evangelho? Como identificar no pluralismo eclesial os elementos que de fato expressam lealdade ao Evangelho e por isso possibilitam um mútuo enriquecimento na fé das igrejas? As respostas precisam ser buscadas. E o fazemos na convicção de que urge superar toda expressão de fé que seja sinônimo de divisão, em todos os níveis da existência cristã. Alguns caminhos para isso: 


\subsection{Inserção no pluralismo}

O modo como nos aproximamos ou nos distanciamos da realidade influencia, e não raro determina, o modo como a compreedemos. O teólogo não é um cientista que analisa um objeto como algo que lhe é distante. O conhecimento teológico tem algo que expressa a relação entre Deus e o ser humano: conhecer é comungar afetivamente. A compreensão teológica requer proximidade, relação, convivência.

Isso diz respeito também ao modo como buscamos compreender o pluralismo eclesial. É fundamental sentir-se inserido na realidade eclesial plural para compreendê-la a fundo. A igreja à qual pertenço não está “acima” ou "a parte” do pluralismo de igrejas. Todas as igrejas com-formam a realidade plural, são elementos dessa realidade. As comunidades cristãs precisam compreender-se inseridas e co-formadas no contexto plural, pertencentes a ele, percebendo que o configuram na mesma medida em que são, de algum modo, por ele configuradas. Não existe uma igreja "aqui" e o pluralismo de igrejas "lá". Existe o pluralismo no qual todas as igrejas se situam.

Assim, a realidade é teologicamente bem compreendida quando vista a partir do seu interior. Isso tem duas principais vantagens para as relações ecumênicas: 1) evita posições de superioridade e de julgamento de uma igreja em relação às outras. Não se pode fazer uma leitura hierarquizada do pluralismo de igrejas, nenhuma vale "mais" ou "menos" do que a outra. Elas não são iguais, mas cada uma responde do seu modo às necessidades espirituais dos seus membros. 2) Possibilita o mútuo enriquecimento na vivência da fé cristã. Nenhuma igreja é tão perfeita que nada tenha a receber do testemunho de outra. Desse modo, o avanço nas relações ecumênicas depende do modo como cada igreja posiciona-se no interior do pluralismo eclesial. Quem se considera "fora" dele está fora também das relações ecumênicas. 
Além disso, é preciso considerar que é o contexto do pluralismo eclesial que apresenta a exigência do diálogo ecumênico, a pauta desse diálogo, seu método e seus objetivos. Apresenta também a perspectiva da unidade cristã que daí decorre. Tem-se, assim, uma prática ecumênica enraizada num espaço e tempo concretos. Claro, na consciência ecumênica além do contexto existem também elementos que o transcendem, como as Escrituras e a Tradição. Mas esses elementos só tem sentido na medida em que são lidos contextualmente.

\subsection{A pluralidade precede à unidade}

É importante compreender que o original da igreja não é a unidade, mas a pluralidade. A base para compreender isso é a origem trinitária da igreja e a multiforme manifestação da graça que nela atua. A Trindade constitui a igreja como espaço privilegiado de sua manifestação. $\mathrm{E}$ a diversidade que existe em Deus justifica a diversidade existente na igreja do mesmo modo que a unidade em Deus exige a unidade na igreja.

É o que Paulo ensina às comunidades cristãs, mostrando que embora muitos todos são animados pelo mesmo e único Espírito de Cristo (1 Cor 12,4). O Espírito concede uma pluralidade de dons, carismas e ministérios. Contudo, tal diversidade só se justifica na perspectiva da comunhão, pois embora muitos os cristãos formam um só corpo (1Cor 10,17). Assim, a unidade/comunhão não aparece como o início da realidade eclesial, mas como a sua meta. Dos muitos, vários, diversos, brota a unidade e a comunhão. Por isso a comunhão é a perfeição da vida cristã e eclesial a ser atingida no futuro.

Isso condiz com a eclesiologia católica ao mostrar que a "variedade de Igrejas Locais, convergindo para a unidade, manifesta mais claramente a catolicidade da indivisa Igreja" (LG 23). Essa igreja tem a pluralidade teológica, litúrgica, disciplinar e pastoral na sua compreensão de igreja, o que muito favorece para o diálogo com a tradição ortodoxa (UR 15-17). O mesmo pode-se pensar da 
teologia ecumênica: ela é elaborada a partir da relação e interação de uma diversidade de posturas teológicas, espirituais, pastorais. De um lado, considerar honestamente essa diversidade é a condição da teologia ecumênica. De outro lado, estabelecer convergências e consensos entre as diferenças é a sua finalidade. O consenso não cancela a diferença, mas o articula de modo a possibilitar que ela seja expressão da comunhão e não algo isolado do todo.

Assim, unidade e pluralidade são correlatas na identidade mais profunda da igreja, sendo a sua divisão total uma impossibilidade ontológica. A diversidade associativa e doutrinal dos cristãos não impede a fé na una e única igreja, obrigando a admitir que para além dos limites institucionais de uma tradição não existe o “vazio eclesial” (JOÃO PAULO II, 1995, n. 13). Urge um pensar sobre a igreja relacionado ao caráter eclesial das diferentes tradições cristãs. Isso é condição para que a comunidade eclesial seja "cristã” e "católica" em toda a riqueza e profundidade de significado desses termos. A preocupação por refletir uma igreja unida afirma, por si mesma, a insuficiência de uma eclesiologia formulada em tempos de divisão.

\subsection{Discernimento}

Outra importante exigência é desenvolver a capacidade do discernimento das diferenças no contexto eclesial plural, identificando quais se integram numa compreensão comum do Evangelho e quais destoam, por expressar divisão na doutrina e fixação exclusivista de posições. É preciso estabelecer critérios comuns para o discernimento, dos quais se destaca o Evangelho. A leitura do pluralismo tem o Evangelho como critério fundamental. O que vale é constatar se o Evangelho é vivido concretamente por cada igreja, mais que o como essa vivência acontece. De um lado, as igrejas têm liberdade para desenvolverem o "como" da vivência evangélica; de outro lado, não é qualquer vivência cristã que se legitima integralmente evangélica. Aí há que se estabelecer um núcleo comum no qual todas se encontram e entendem que, de fato, vivem o mesmo e único Evangelho. Onde 
estaria esse núcleo comum? Entendemos ser a mensagem do Reino. Tal seria o critério normativo para uma verdadeira vivência do Evangelho de Cristo.

No exercício do discernimento dois outros fatores são importantes: a) evitar toda conciliação fácil ou concessão que negue as diferenças em nome do uniformismo. O que se busca é identificar as diferenças, não negá-las. Uma vez identificadas, as diferenças podem ser trabalhadas nos elementos que apresentam potencial de conflito e divisão. Tem-se, assim, a comunhão na diferença reconciliada. b) compreender que aquilo que é diferente nos outros exige respeito, mesmo que ainda não seja possível compartilhar. Não valorizamos o outro apenas por aquilo que nele nos interessa. Ele tem valor por si mesmo. E pode haver elementos na sua expressão da fé cristã que ainda não conseguimos relacionar com a nossa forma de ser cristão. Não significa que essa diferença não possa ser reconhecida em sua legitimidade como constitutiva da identidade religiosa do outro; significa que ela não pode ser acolhida como constitutiva da minha identidade. Por isso a comunhão entre as igrejas é ainda parcial, limitada, não plena.

\subsection{Revisão dos pressupostos da separação}

Outro fundamental exercício a ser feito para compreender o pluralismo eclesial é reinterpretar as razões que justificam o modo próprio de ser de cada igreja que compõe esse pluralismo. O estado atual do pluralismo eclesial não pode ser justificado apenas pelas causas do passado, não é suficiente olhar o passado para legitimar o presente. Precisa-se de um novo olhar, capaz de reinterpretar as razões que em outros tempos e circunstâncias sustentaram as divisões para ver se os seus pressupostos são ainda válidos para os tempos e circunstâncias atuais. O objetivo é superar a divisão sem cancelar o pluralismo eclesial. Não se trata de negar a história ou a tradição das igrejas. Mas de compreender que cada uma é chamada a rever sua história e sua tradição em vista da superação e mesmo do abandono das heranças de divisão. Outrora, razões políticas e sociais mesclaram-se 
com razões teológicas para justificar posições divisionistas. Em contextos de controvérsia intensa, questões semânticas e de linguagem obscureceram o conteúdo comum da fé, e posições extremistas e unilaterais tiveram fundamentos mais ideológicos do que teológicos. Em nossos dias, não só mudou a situação histórica na qual as posições originais foram criadas. Mudou também o método e a impostação dos problemas teológicos, possibilitando novos modos de ver as diferentes igrejas.

A questão a ser respondida é se, de fato, as razões do passado possuem no presente o mesmo potencial de divisão da igreja. A história caminhou, e é preciso reavaliar os "pressupostos da separação" (RUGGIERI, 2000, p. 14). As igrejas atingiram consensos e convergências que fazem com que não seja tarefa simples afirmar hoje razões teológicas consistentes para manter o distanciamento mútuo. Acordos alcançados mostram que o conteúdo comum da fé continuou existindo mesmo quando, por séculos, as igrejas pensaram estarem teologicamente divididas.

Por isso, há que se buscar as razões que, no presente, possuem força de divisão e entender como e em que medida podem ser superados. Na atualidade as igrejas podem manter suas histórias, tradições e diferenças sem conservar os motivos que, outrora, criaram exclusão mútua. Outrora, as razões particulares das tradições eclesiásticas foram determinantes para a divisão. No presente, a superação desse estado exige que as razões particulares das igrejas não sejam o fator determinante para as relações intereclesiais. O determinante é o Evangelho. Um novo olhar sobre as divisões no mundo cristão, à luz do Evangelho, implica na tarefa de rever os pressupostos das tradições eclesiais particulares, detectando os elementos do passado que continuam a operar ainda hoje para a continuidade da divisão, aqueles acrescentados pela história recente, e os que contribuem para a percepção de uma comunhão já existente no contexto do pluralismo eclesial e que tem possibilidades de crescer. 


\section{Conclusão}

Sob o pecado da divisão na igreja e acima dela, existe a graça de Deus. Assim como o pecado não cancela definitivamente a graça na vida do fiel, também não cancela definitivamente a unidade na Igreja de Cristo, pois ela é uma "divina vocação" e uma "graça" (UR 1) dada pelo próprio Senhor. Da parte humana urge superar o pecado e as anomalias que ele causa no corpo histórico da igreja. Lutar para superar as divisões é abrir-se para a graça que expressa na unidade dos discípulos a natureza mesma do que Deus é, uno e diverso. O Espírito é o vínculo da unidade em Deus. E assim também o é na igreja (Ef 4,3). A unidade do corpo depende da unidade no Espírito que o anima. E a unidade no Espírito precede à unidade do corpo.

É a graça que leva cada igreja a superar situações de divisão como uma responsabilidade própria e comum ao mesmo tempo. $\mathrm{O}$ diálogo permite às igrejas descobrirem sob as diferenças um acordo que as une, mesmo se ainda não se acolhem mutuamente de forma plena. A graça de Cristo não lhes permite ignorarem-se reciprocamente:

a mesma intensidade das nossas divergências testemunham uma convicção comum que vem d'Ele: o corpo de Cristo é uma unidade que nos proíbe seja de nos ignorarmos mutuamente, seja de nos conformarmos com um acordo apenas sobre alguns aspectos da fé, deixando outros não reconciliados. (CONSELHO MUNDIAL DE IGREJAS, 2001b, n. 10).

Portanto, há um mistério no pluralismo eclesial, impossível de ser apreendido totalmente pela razão humana, que nos leva a pensar que

Deus pode tirar o bem até mesmo das situações que ofendem o seu desígnio, podemos então descobrir que o Espírito fez com que as oposições servissem, em algumas circunstâncias, para explicitar aspectos da vocação cristã, como sucede na vida dos santos. Apesar da divisão, que é um mal de que nos devemos curar, todavia realizou-se como que uma comunicação da riqueza da graça, que está destinada a embelezar a koinonia: a graça de Deus estará com todos aqueles que, seguindo o exemplo dos santos, se esforçam por favorecer as suas exigências. (JOÃO PAULO II, 1995, n. 85). 
Assim, na perspectiva da fé que nos permite discernir a presença da graça mesmo em situações de desgraça, Oscar Cullmann afirmou em uma conferência sobre a história da salvação no Novo Testamente, na Igreja São Luís dos Franceses, Roma, em 02/12/1963:

Pode-se descobrir a mão de Deus no nosso cisma, qualquer que seja a nossa falta. A diversidade das Igrejas é uma admoestação constante relativamente a nós para que respeitemos a diversidade dos dons do Espírito [...]. A história da salvação avança, apesar de nossas imperfeições e dos nossos pecados. (CULLMANN apud FESQUET, p. 345).

Trata-se de uma visão de fé, que reconhece a ação da graça na história da igreja mesmo quando fatos dessa história expressem ambiguidades e contradições. Diante desses fatos a fé cristã não sucumbe ao negativismo, mas reafirma a confiança e a esperança em Deus, projetando uma nova realidade para a sua igreja, de superação do que a impede viver a sua natureza de comunhão e a sua fidelidade à missão de cooperar com o projeto de Deus de reconciliar tudo e todos em Cristo (Col 1,20; 2 Cor 5,18).

\section{REFERÊNCIAS}

COMISSÃO INTERNACIONAL CATÓLICO-LUTERANA. Martin Lutero testimone di Gesù Cristo. In: CERETI, Giovanni; PUGLISI, James F. (ed.). Enchiridion Oecumenicum. Bologna: Edizioni Dehoniane, 1986a. v. 1, p. 743-751.

COMISSÃO INTERNACIONAL CATÓLICO-LUTERANA. Tutti sotto uno stesso Cristo. In: CERETI, Giovanni; PUGLISI, James F. (ed.). Enchiridion Oecumenicum. Bologna: Edizioni Dehoniane, 1986b. v. 1, p. 693-701.

COMISSÃO INTERNACIONAL CATÓLICO-LUTERANA. Vie verso la comunione. In: CERETI, Giovanni; PUGLISI, James F. (ed.). Enchiridion Oecumenicum. Bologna: Edizioni Dehoniane, 1986c. v. 1, p. 693-701.

COMISSÃO INTERNACIONAL CATÓLICO-ORTODOXA. Il mistero della chiesa e dell'eucaristia alla luce del mistero della santa Trinità. In: CERETI, Giovanni; PUGLISI, James F. (ed.). Enchiridion Oecumenicum. Bologna: Edizioni Dehoniane, 1986d. v. 1, p. 1028-1042. 
CONCÍlIO VATICANO II. Documentos do Concílio Ecumênico Vaticano II. São

Paulus: Paulus, 2007.

CONSELHO MUNDIAL DE IGREJAS. Assemblea de Amsterdã (1948): relatório das seções. Rapporti delle sezioni. In: CERETI, Giovanni; PUGLISI, James F. (ed.).

Enchiridion Oecumenicum. Bologna: Edizioni Dehoniane, 2001b. v. 5, p. 8-47.

CONSELHO MUNDIAL DE IGREJAS. Assemblea de Evaston (1954): rapporti delle sezioni. In: CERETI, Giovanni; PUGLISI, James F. (ed.). Enchiridion Oecumenicum. Bologna: Edizioni Dehoniane, 2001a. v. 5, p. 87-198.

CULLMANN, O. L'unité par la diversité: son fondament et le problème de sa réalisation. Paris: Cerf, 1986.

FÉ E CONSTITUIÇÃO. I Conferência Mundial: Lausanne, 1927. In: CERETI, Giovanni; PUGLISI, James F. (ed.). Enchiridion Oecumenicum. Bologna: Edizioni Dehoniane, 2005. v. 4, p. 5-437.

FESQUET, H. O diário do concílio. São Paulo: Publicações Europa-América, 1967. v. 1.

GRUPO DE DOMBES. Per la conversione delle chiese. In: CERETI, Giovanni; PUGLISI, James F. (ed.). Enchiridion Oecumenicum. Bologna: Edizioni Dehoniane, 1999. v. 4, p. 306-402.

JOÃO PAULO II, Papa. Carta encíclica Ut unum sint do santo Padre João Paulo II sobre o empenho ecumênico. São Paulo: Paulinas, 1995.

JOÃO PAULO II, Papa. Discurso aos membros do Conselho da Igreja Evangélica (Alemanha) 17/11/1980. Disponível em http://w2.vatican.va/content/john-paulii/pt/speeches/1980/november/documents/hf_jp_ii_spe_19801117_chiesaevangelica.html. Acesso em 9 out. 2018.

KASPER, W. Chiesa cattolica: essenza, realtà, missione. Brescia: Queriniana, 2012.

KLOPPENBURG, B. Concílio Vaticano II. Petrópolis: Vozes, 1964. v. 3.

RUGGIERI, G. Alle radici della divisione. In: RUGGIERI, G. (org). Alle radici della divisione: una rilettura dei grandi scismi storici. Roma: Ancora, 2000.

THILS, G.. Historia documental del movimiento ecumenico. Madrid: Ediciones RIALP, 1965.

WOLFF, Elias. A unidade da Igreja: ensaio de eclesiologia ecumênica. São Paulo: Paulus, 2007. 